\title{
Constitutional Values: An Exploratory Study of the Constitutions of Bavaria and India
}

Christian Alexander Bauer* and Harald J Bolsinger ${ }^{\star}$

\section{Abstract}

This article is an attempt to understand "Bounds of Ethics in a Globalized World", the hiatus between principles, norms and values and how they are codified on the one hand and the risks that follow when the actualisations of regulative principles fail in political reality on the other hand. Considering the political, economic and social reality, it is frequently diagnosed that reality is lagging far behind the potential of constitutionally guaranteed rights and duties. A variety of constitutionally guaranteed values suffers from devaluation. Taking examples from Bavaria in Germany, questions concerning whether the Bavarian society is at the borders of ethical capacities, or whether the limits of possible ethical regulation have been reached are dealt with. Important parallels in the genesis of the Bavarian and the Indian constitution are highlighted in this context. Through an understanding of the ideas of Ludwig Erhard, a pragmatic approach and an innovative model is proposed for cultivating values in a sustainable way. The importance of values of virtues is discussed and an emphasis is put on the importance of practiced virtues.

Keywords: Politics, Constitutions, Bavarian constitution, Indian constitution, Value

* University of Applied Sciences, Wuerzburg, Germany; christian.alexander.bauer@fhws.de

$\dagger$ Faculty for Economics and Business Administration, University of Applied Sciences, Wuerzburg, Germany; Harald.Bolsinger@fhws.de 


\section{Introduction: Politics, Constitutions and Markets}

According to the political philosopher Hannah Arendt politics takes as a basis the practice of voluntary agreement of free citizens (Gerhardt, 2010). The European conception of politics has been founded on this apprehension of polis and res publica ever since the ancient times. For this voluntary communication to be guaranteed, Free States, as for example Bavaria, gave themselves a constitution in order to achieve that moral principles will not only be evoked theoretically but become a powerful part of the political sphere of action as constitutionally legitimated and approved basic rights.

The Bavarian and the Indian constitutions were developed in almost the same period of time. Bavaria became a Free State in 1946 after the liberation of Germany by the allied forces. The allied occupation of Bavaria by the US-Forces proved to be benedictional for the buildup of the civil society. In February 1946, the military governor General Clay commissioned the composition of a new constitutional order for the federal states (Willoweit, 2013). But it was only after the Constitution of the Federal Republic of Germany (the so called "Grundgesetz") came into force on May 23 $3^{\text {rd }} 1949$, that Bavaria became a part of the federalistic system of Germany. Before that the Bavarian Parliament (the so called "Landtag") refused to accept the "Grundgesetz", but in the case of its coming into force, Bavaria acclaimed her belonging to the Federal Republic of Germany (Zippelius, 1998). The Indian Constitution is the result of a constant struggle for rights in the Post-World-War-Period as well. After the Indian Independent Act, which came into force on August 15th 1947, the long period of British rule ended (Zippelius, 1998). After a long struggle the new constitution of India was adopted on November $26^{\text {th }} 1949$ and came into force on January $26^{\text {th }}$ 1950 (Pandey, 2013).

Because of historic experiences, the prospect of legal certainty was the determining factor for the representatives of the people in India and Bavaria. They elaborated functioning constitutions integrated their fundamental ideological principles quite naturally. These constitutions were on the one hand supposed to satisfy the principles of a separation of powers as well as the independence of 
justice. On the other hand, the Indian and the Bavarian constitution are characterised by their aspirations to balance social injustice by striking a balance between individual liberty and social need Pandey, 2013). The enforcement of these attempts was understood as a guarantee for social and national cohesion by the founding fathers of the respective constitutions. In this context, the observations of the US-American historian Granville Austin are of interest: In the preface to his standard work, The Indian Constitution: Cornerstone of a Nation, Austin writes that it is a mistake to suppose that a constitution is either utterly functional or not. The point is rather this: "Constitutions do not 'work', they are inert, dependent upon being 'worked' by citizens and elected and appointed leaders" (Austin, 1966).

According to this conception, amounting to a comprehensive ethos implied by a constitution, it is obvious that the idea of a constitution results in a vitalisation of value resources, which must first and foremost become manifested by the virtue-ordered practices of the citizens. On the one hand the constitutional directives constitute a claim of norms. On the other hand one can focus on the ethical motivation of citizens who cause effects beyond the representatives of judiciary, executive and legislative authority. They exert themselves not only in their negotiation of questions concerning socio-economic value, but strive actively for the actualisation of highest assets such as human dignity in their daily communications. A similar understanding is valid for the structure of markets which are built on moral fundaments that they have not and cannot create themselves. The constitutions make up a normative framework which in the first place stands for a purpose and not necessarily for something already existing (Dohrmann, 2002).

Considering the political, economic and social reality it is frequently diagnosed that this reality is lagging far behind the potential of constitutionally guaranteed rights and duties. The inbuilt drift of the last decades demonstrated that quite a variety of constitutionally guaranteed values and this also concerned human dignity suffer from an increasing devaluation. Economic and social ethicists thus had to wonder, whether the Bavarian society with respect to societies in general bounce more and more at the borders 
of ethical capacities, or whether the limits of possible ethical regulation have been reached. As the philosopher Thomas Pogge argues in World Poverty and Human Rights. Cosmopolitan Responsibilities and Reforms commitments of ordinary citizens regarding human rights are in many cases more reliable then the confessions of political executives (Pogge, 2011). Furthermore, he is convinced that the communal ethos of virtue and solidarity often provides a better access to humanity than the actionable laws of a society (Pogge, 2011, p. 286). It seems as if political practice has to renew itself as a political field of action: Citizens must once again take matters of political significance into their own hands by public participation and that means a renewed interest in grass root mobilisation that must eventually lead to new representative structures of public law. The action-coordinating knowledge of Ethics can provide worthwhile contributions of ideas that might motivate and qualify citizens to question principles and to debate democratically about the advisability as well as about the means and ends of common welfare action. The citizens could refer to the Nicomachean Ethics of Aristotle for example, which was designed as a "science of politics" (Aristotle, 1863).

\section{Functions of Values and their Foundations}

Values are an omnipresent issue. In contemporary discourse, values become ambiguous, a term that includes various things: Laws, norms, commands, prohibitions, duties, virtues, ethos, customs, culture; social institutions as democracy, family and other concepts are often called values in everyday discourse. The distinctness of what values are often suffers from this. The publicity of the concept of value rose due to the explicative character in national economy and its reflection on the society and its order (Folke, 2002). Via this application, it also found access into philosophy that had formerly and primarily been occupied with virtues. The history of political economy demonstrates a broad variety of interpretations regarding the meaning and function of value concepts.

For Thomas Hobbes (1588-1679), a value is no objective property, but ascribed to the given object and situation by the individual depending on the subjective perception by the categories of 
'pleasing' and 'unpleasing'. According to John Locke (1632-1704), value follows from the utility of goods to satisfy people's needs. The utility can be determined by the work that is required to produce goods. The utility-concept is connected with the labour value-concept. In the thoughts of David Hume (1711-1776), a value is seen as the effluence of personal interest: it promotes personal lust and reduces dislike. Here utility is the only source of valuation and the core of morality that refers to the environment and fellow man. With Adam Smith (1723-1790), we see a differentiation of practical and exchange value. The value of a good is determined objectively in his market relation by the amount of work that is received in exchange for the given good. The revenue that is attained for the good on a specific market becomes the most important factor of value determination. Value is represented in purchasing power for work. Jeremy Bentham (1748-1832) and John Stuart Mill (1806-1873) go their way from exchange value back to the utility principle (utilitarianism). The only relevant criterion for the evaluation of goods and actions is the individual utility, which was in further development extended to include the utility of all in general wealth.

Values are associated with an appellative character and with strong preferences. Good values are associated with ethics, morality and moral conventions. A subject preferring and advocating certain values can feel strong subjective bonds to these values: They become generally binding. Looking at values from a philosophical point of view shows up four central concepts: In subjectivism, the objectivity and application of values is not fixed. Values are defined dependent on the subject and his/her beliefs. Relativism wants to make clear that values are empirically ascertainable relative parameters in a specified context, depending on cultural and other conditions. Realism states that values are connected with human existence and refer to one highest value, e.g. God. Idealism separates values from the individual being and tries to find the objective good as a formal ought (e.g. the categorical imperative).

When we review of all these value concepts, we identify two poles of the value-concept that still lack compatibility with each other in economical and philosophical schools to this day. We can speak of a bipolar character of the value-concept claiming objective 
standards on the one hand and showing its roots in subjective individual value-determination (Folke, 2002, p. 129). The objectivity of values and thereby, the claim of binding character requires the use and recognition of good and evil as generally binding categories. Objectivity thus depends on categories external to the contemplator that enable judgments of good and evil as well as a classification of values. Single values are therefore not suitable for objective standards if they are communicated without further foundation. To well-found values, absolute standards are needed which can objectify the values, for example the reference to the Human Rights of the UN or other catalogues of norms like the Ten Commandments in Christianity. As a normative criterion values fulfill at least three functions: They regulate by directing human action at a desired target, they enable legitimation and justification of actions in their relief function and they simplify decisionmaking.

From all this we see, that values are some kind of 'social glue' that connects and binds together cultures, religions and worldviews. Values are institutionalised in binding catalogues as norms. As norms they can be used as basis from which one can construct argumentations founded in ways broadly accepted. So looking at norms, for example constitutions of nations means looking at the potentiality of value-orientated argumentation in a respective nation or group of people. Still, using values for orientation requires a 'safety net'. Values are in need of constant reflection and assessment by superordinate standards. Value systems have to be applied in a situation-sensitive manner and are in need of a frequent critical reflection. They need to be refused or changed if necessary.

\section{The Constitution of Values}

The Constitution of the Bavarian Free State became effective on December $8^{\text {th }} 1946$. The preamble reflects the historic experiences of World War II. The substantial destruction in Germany covered large areas. Furthermore, principles, norms and value orders that were awfully and inhumanly distorted by national-socialistic leadership demanded to be build up including mental customisation of the people as well. The grounding fathers of the 
Bavarian Constitution shared the conscience that one has to immunise against a repetition of the national-socialistic terror. In more than one respect, the rules and regulations of the constitution show a learning process that is reflected in a row of articles that address common welfare explicitly. The following list includes at first some examples of the Bavarian Constitution. In several cases we indicate some concordances with regard to contents of the Indian Constitutional Law:

- Economic profit seeking and striving for power in economy were limited in general by restrictions and laws. Due to this Article 3 proclaims: "Bavaria is a legal, cultural and social state. It shall be dedicated to the common well-being."

- Article 114 speaks about "freedom of association" and proclaims that citizens have the right to unite in associations and coalitions: "All residents of Bavaria shall have the right to assemble freely and to form associations and corporations." The Indian Constitution guarantees in Article 19(1) (c) "to all its citizens the right 'to form associations or unions or Co-operative Societies." (Pandey, 2013, p. 219).

- Article 124 addresses questions/rights about marriage and family proclaims that families are given special protection against assaults of any kind: Marriage and the family are the natural and moral basis of human society and shall enjoy the particular protection of the State." Besides this, partners have equal rights and obligations: "Men and women have fundamentally the same civil rights and obligations within the marriage." In turn the Indian Constitution provides a special provision for women and children in Article 15 (Pandey, 2013, p. 136).

Besides that, the following topics that regard the actualisation of legal principles that represent challenges to the economic sphere: In article 151 where the economic system is defined (in the German version entitled with commitment of economic activity to common well-being, basic principles for freedom of contract) the following is proclaimed: "(1) The entirety of economic activity shall serve the common well-being, in particular a guarantee of dignified existence for all and a gradual enhancement of living standards for all 
sections of the community, (2) Within this aim, freedom to contract within the law shall be upheld. The fundamental individual freedom to develop personal enterprise and to engage in independent economic activity shall be recognised. Economic freedom of the individual shall be consistent with consideration for others and the moral demands of the common well-being. Socially damaging and immoral economic activity, in particular any economically exploitative contract, shall be illegal and void."

- Article 157: Finance and credit systems: “(1) The accumulation of capital is not an end in itself, but rather a means to the development of the national economy."

- Article 167: Protection of labour: "(1) As the most valuable economic resource of a people, human labour shall be protected against exploitation, occupational hazards and other threats to health." The Indian Constitution declares rights against exploitation as well by Article 23, which "prohibits traffic in human being and beggar and other forms of forced labour" (Pandey, 2013, p. 343).

- Article 168: Remuneration; unemployment and sickness welfare provision: “(1) Every honest form of employment has an equal moral value and a claim to appropriate remuneration. Men and women shall receive equal pay for equal work." The aspect of equal pay for equal work is also considered in the Indian Constitution as "a constitutional goal under Articles 14, 16 and 39 (c)" (Pandey, 2013, p. 152).

The equivalences in the Bavarian and the Indian Constitution incorporate entitlements, which should protect citizens against an unjustified economical assault upon their existence.

\section{Entitlements and Reality}

The Bavarian Constitution stands for rules and regulations and thereby for a claim, although the so-called, reality of this constitution in no way does justice to these rights in a number of respects. One can ask whether it is ignorance or an excessive ethical demand or maybe a lack of loyalty to the constitution that impedes a convergence of social reality on the one hand and the spirit of 
laws on the other hand. The discourses of the political and public sphere and not least of judiciary set place in a free democratic order. Thematically they broach the abuse of power, corruption and the lack of realisation of basic law. Under consideration are for example cases in which articulations of high moral demands are responded to by hinting at the ethical over-demands they involve. Politics is after all also a struggle for power guided by people's interests (Max Weber), an antagonism, that becomes not least apparent in matters of business life. Politics is as well the fight for right, and in a democratic society every citizen is involved in this conflict. Especially those citizens who want to realise high moral and ethical standards in daily life are confronted with economic, social and political realities whose hierarchy of principles (as for example the implicit norms of social market economy and of common welfare orientation) are not only realised in limited degrees but rather suffer from a successive consumption by particular but nevertheless dominant interests of powerful groups. The social value conflicts that occur more and more because of the hiatus to the constitutionally warranted values, and that cannot be solved simply by law or political adjustment, are therefore up for discussion.

To both function structures - law and politics - as well as to the economic sphere applies the observation of the German sociologist Niklas Luhmann that thitherto nobody, neither as person nor as authority or institution, has succeeded

[...] in combining reliably the many undeniable values and non-values - and in finding a common ground and consensus. Values always eliminate their opposite - with open flanks. And this means that although values can mark consensus-capable aspects or considerations of a whole society, decisions always have to be made in the function systems and their specific organizations respectively in private and are determined exclusively by the relevant system. In economic decisions they are made by the economy itself, by the company or the private household which has to calculate with a narrow income (Luhmann, 2008, p. 197). 
In view of these ambivalent circumstances citizens feel defiant to question, whether they should react with a devaluation of their individual pretensions upon their virtuous practice. Or, if they should, on the contrary, act as zoon politikon by heightening exemplary and ethically justifiable representations in their life and action. Given the fact that citizens are willing to accept the regulative capacities of Ethics, it will appear as an unconditional demand for them as social protagonists to reflect upon the question what meaning values have for them at all and whether it is possible to derive a universal imperative or norm from these values.

\section{The Importance of Values and their Ranking}

If it is acknowledged in a reflected manner that the social discourse about the status of values will lead to "a multiplication of valuable relations while relations between values will be left open" so that "the value of values" must always remain undefined and must only be determined contextually. Only then does the predicament of democratically controlled discourses about values become evident (Luhmann, 2008, p. 182). Any stabilisation of social conditions affords and implies choices and negotiations about the relevant semantics of values that everybody can select and exploit according to his own purposes. While Hannah Arendt meant that a genuine political practice consists of the voluntary communication of free citizens, in the event horizons of these days, politics is condemned to be a virtuosic juggling with conceptions of values.

Not least because of this, every political agenda that claims constitutional significance of certain values has to justify its ideological premises as it accentuates particular constitutional principles. The representatives of parties, the political class and their deputies are called on to recognise that it is only possible to find a way out of the vicious circle that is caused by a constant shifting of value-semantics by a consensus about some kind of value hierarchy. This consensus can only come about through broad public participation and will only then rightly bear the courtesy title of "consensus". The question whether democratic adjudication in four-year-terms (as in elections to the German Federal Parliament "Bundestag") or in five-year-terms (as in elections to the Bavarian State Parliament "Landtag") is the 
ultimate appropriate solution for such a culture of consensus is to some extent denied by the practice of the referendum. The experience of past decades has shown that this political instrument has to be used whenever decisions of high relevance which include a reference to accepted values are on the political agenda. That applies in particular when it is the overall aim to achieve a stable and durable compliance to political issues of vital importance. The instrument of referendum provides for the dynamics that are inherent to value orders (Dohrmann, 2002, p. 5). Against this background the initial design of Bavaria as a cultural state ("Kulturstaat") appears plausible: The active maintaining of this cultural state must lead to a process in which the sum of values is preserved and their particular core is frequently deliberated. This dynamic order of values is reflected in cultural action and development.

In his paper, "A Social Democratic Agenda for a More Dynamic Indian Economy: Creating an Innovative and Learning Society", Joseph E. Stieglitz wonders whether economic policies exclusively contribute to the well-being of citizens. He underlines that the success of social development and societal transformation depends on the general belief systems and cognitive frames of a society: "The acceptance and performance of institutions depend not only on economic variables, but also on the set of general beliefs about the world, which can at any moment be treated by state variable. Collective beliefs that emerge in one period shape the possible institutions in the next" (Stieglitz, 2013, p. 298).

The criterion for good economical action is often reduced to the economic principle in numerous publications. The aim is conceived as the maximisation of the so called 'utility' (often understood as 'profit' or the consumer's happiness due to consumption) or as the minimisation of effort to achieve a given level of utility. The mechanism of coordination which is supposed to generate universal wealth from individual egocentric utility is the invisible hand of market'. At first sight acting according to this principle thus seems to be a sufficient ethical fundament for market organisation - directed at an allegedly economical handling of scarce resources. A large number of wrong decisions has generated the pursuit of an unconditional profit maximisation on the side of 
the entrepreneur and utility maximisation on the side of the consumer as the epitome of allegedly good - i.e. efficient economising. On the basis of this, almost all fundamental achievements of human life have been called into question. Child slaves are coerced to harvest cocoa beans thereby damaging their health in order to maximise the profit of food companies and satisfy the consumers' desire for cheap chocolate. Financial institutions produce valueless certificates for their profit maximisation and thereby chisel people - who strive for their own profit maximisation - out of their retirement provisions. Companies dump garbage into the sea to save waste removal costs on behalf of their shareholders. Companies achieve billions and simultaneously dismiss a multitude of staff to further heighten the profit of their shareholders. Women are often still paid less for the same work as men. There are many more examples that can be cited to validate the assertion.

A meander and fetish has arisen that is nowadays ever more to be disenchanted. It is hidden in the commitment of rational agency under alleged conditions of scarceness. It is mediated and taught as an allegedly ethical desirable model for economical action under competitive conditions and it is stylised as an orientation norm in all social contexts. Ludwig Erhard - one of the most important founders of the social market economy - noted in his Wohlstand für Alle (Wealth for all) that the isolated over-emphasis of profit maximisation amounts to a meander:

We have been befallen by an uncertainty. Not only our brains but also our hearts and souls have been caught by confusion. Perhaps - I actually mean it is for certain - many of us have been misled by the necessary direction of all human powers to the retrieval and protection of our material livelihood. An adequate feeling for the hierarchy of values has thereby gone missing. Whether we can solve the irrefutably posed questions successfully will be our fortune (Erhard, 1964, p. 330).

Hinting at the hierarchy of our values, Erhard shows that maximisation of profit and materialism cannot always stand above everything else. He rather implies that other values should 
influence our actions and aims. Put in a contemporary language this becomes clear in the 'Triple Bottom Line' of the sustainability paradigm. Here, social, ecological and economical aims stand equally in the focus of economical action. In a government declaration from October 1963, Erhard avows himself to a 'Christian ethos and responsibility' and provides a philosophical and worldview justification for 'his' hierarchy of values. The argumentation with values as it is suggested by Ludwig Erhard can be structured into four steps of a value-orientated argumentation:

1. One starts by recognising a prejudice or preference of his own and formulates an ethical question that might arise from it. This means taking off one's own philosophical glasses and getting involved with an unbiased analysis of facts, assumptions and values. At this stage it is important to identify relevant parties of conflict and their interests as well as underlying values and norms

2. A further step aims at establishing a hierarchy of values: One tries to form a reasonable hierarchy from the found values by regarding his own preferences and showing the practical consequences that ensue. He weighs the values against each other in order to build up a reasonable hierarchy. In case of equally ranking values one can try to justify hierarchies for concrete cases.

3. Imperative: From the chosen hierarchy of values an imperative derives. At this point it is possible to answer the initially set ethical question on the basis of the given hierarchy of values. Identifying the ensuing aim and positioning oneself as clear as possible is important at this stage.

4. Credo: In the credo one can compress and summarise a recommendation for someone who is looking for valueorientation. This includes asking the initial question, pointing out the most relevant values in the respective context as well as their justified hierarchy and giving a clear recommendation for action.

Especially when the organisation of our future is at issue, to responsibly justify decisions not only requires the reference to the 
highest possible profit but also provide answers that reach beyond the economical category. Economical action is an ideologically affected arrangement of values and norms. Being responsible means being able to give answers that make use of the variety of different values in a plausible way, clarify and make transparent our 'will' in his whole foundational make-up.

\section{Circulos Virtuosus}

Starting from the diagnosis of value problems and conflicts we negotiated the hiatus between the principles, norms and values and how they are codified on the one hand and the risks that follow when the actualisations of regulative principles is doomed to fail in political reality on the other hand. The bounds of applied ethics can be demonstrated by referring to the Bavarian constitution in certain respects. The self-discipline of the Bavarian society can certainly benefit from the arguments, coherencies of justification and methods of resolution as they are offered by economic and social ethics as well as by applied ethics in general. But the crucial point is that values sail in ballast when they are not part of practiced virtues and lack concrete 'fruits of action'. Values remain unpracticed virtues as long as the labour on oneself is not initiated and thus also the examination of one's own guiding principles does not take effect. Anyone who is not disposed to examine himself, cannot judge morally about others in a serious way, too. The vicious circle of value conflicts cannot be broken until citizens join the circulos virtuosus that is set out to work on their personal contribution and start to care about the fruits that only a concrete practice of values and virtues can bring about.

Our society demands rightly plausible justifications for economical action and accountability of the entrepreneurs' decisions postcrisis, scandals and wrong decisions. It does not suffice anymore to refer to profit-related interests only. How does the value based deliberative process really look like - or has it even taken place 'valueless'? What does the stand behind the engagement concerning sustainability and corporate responsibility entail really? (Bolsinger, 2013, p. 6) How do companies come to define the responsibility "for their effects on society" (CSR-definition of the European Commission; Oct. 2011) in a concrete case? The 
respective answers given to these issues can be explained by the catalogue of enacted values and their hierarchy as they are deemed valid - eventually even by the ideological foundation of these values. The Ethics of economy, society and communication has to fathom the limits of the actualisation of human dignity on the basis of positive legal orders. Furthermore, they must constantly insist on heightening chances for human realisation (compare the Capability Approach of Amartya Sen). The promotion of external and internal freedom is supposed to be the aim. Against the background of activities that are guided by common well-being one should further advocate a better (because fairer) coexistence so that all citizens can consider themselves as members of a "fruitful society".

\section{References}

Aristotle, A. W. T. (1863). Aristotles' nikomachische ethik.

Austin, G. (1966). The Indian constitution: Cornerstone of a nation/ Granville Austin. New Delhi: Oxford University Press.

Dohrmann, J. A. (2002). Directive principles of state policy in der Indischen Verfassung. ERGON, Würzburg.

Erhard, L. (1964). Wohlstand für Alle (8th ed.). Düsseldorf: Econ-Verlag.

Folke, W. (2002). Vom wert der werte. Münster: LIT-Verlag.

Gerhardt, V. (2010). Existentieller liberalismus. Merkur, 64(9), 893-904.

Luhmann, N. (2008). Die moral der gesellschaft. Frankfurt: Suhrkamp Verlag.

Pandey, J. N. (2013). The constitutional law of India (50th ed.). Allahabad: Central Law Agency.

Pogge, T. (2011). Weltarmut und menschenrechte. Kosmopolitische verantwortung und reformen. Berlin, New York: de GruyterVerlag.

Stieglitz, J. E. (2013). A social democratic agenda for a more dynamic Indian economy: Creating an innovative and 
learning society. In S. Khilnani, \& M. Malhoutra (Eds.), An Indian social democracy: Integrating markets, democracy and social justice. New Delhi: Academic Foundation.

Willoweit, D. (2013). Deutsche verfassungsgeschichte. Vom Frankenreich bis zur wiedervereinigung Deutschlands. Ein studienbuch (7th ed.). München: C.H. Beck-Verlag.

Zippelius, R. (1998). Kleine Deutsche verfassungsgeschichte. vom frühen mittelalter bis zur gegenwart ( $4^{\text {th }}$ ed.). München: C.H. Beck-Verlag. 